\title{
Emotions as an Aspect of Respect among Adolescents
}

\author{
Priyanka Panwar* \\ Department of Human Development and Childhood Studies, Lady Irwin College, \\ University of Delhi, New Delhi, India \\ *Corresponding author
}

\section{A B S T R A C T}

\section{Keywords}

Adolescent,

Respect, Emotion,

Feelings, Empathy,

Fear, Reciprocity

Article Info

Accepted:

07 September 2019

Available Online:

10 October 2019
Adolescence is a period which is marked by various changes and challenges in adolescents' life. The adolescents' approaches in dealing with those challenges are primarily influenced by their behavior which depends upon their emotions. Each and every individual is distinctive in their behavioral characteristics which mean that they have different feelings and emotions. The respect for every individual's feelings is important in order to maintain a healthy relationship and environment. Respecting someone's emotions implies that the person is valued and acknowledged. So, the present study was designed to study various emotions that are associated with respect. For this purpose, 50 school going adolescents in the age group of 14-15 years were selected from Sikandra Road, New Delhi, India. The tools used in this study were vignettes, interview schedule and observation. The major findings of the study were that emotions like happy, content, proud, anger, guilt, remorse and shame are felt when a person is respected or disrespected. Respect as a result of fear of authority was also discovered in the study. It was revealed that love and fear were the core emotions that drive the display of respect. There is always a give and take of something which is also observed in case of respect.

\section{Introduction}

Respect is central for a person living in a civil society and critical to constructive human relations (Shwalb and Shwalb, 2006). Respect is considered as positive and necessary which indicates that it is important for valuing people and things. Respect means to treat a person or thing with care and concern (Shwalb and Shwalb, 2006). Respect is shown to others by giving them realistic positive consideration, acknowledging them, listening with careful attention and providing suitable gratitude (Lawrence-Lightfoot, 2000).

The word 'respect is originated from Latin remeaning 'again' and specere meaning 'to look', which means 'to look again' or to notice with attention'. The opposite word for respect is disrespect. Disrespecting someone 
simply means to insult or humiliate a person (Lawrence-Lightfoot, 2000). According to Hill (2000), an individual should be respected as he/she has a rational nature, so they should be respected like other things of remarkable value and consequently protected and appreciated.

Every human being is unique in his/her nature and have different feelings, and behaviours. So, it becomes important to understand others feelings and have respect for the feelings of others. Respect for feelings of other people helps in encouraging them to express their emotions and experiences which strengthen their bond.

\section{Perspective on respect as an emotion}

Kant gave two concept of respect as an emotion: firstly, respect is the only emotion that has an association with cognition, and secondly, respect is the only emotion that aids as an enticement for morally praiseworthy deed.Kant believed that emotions in respect are a class of feelings which can be positive or negative. Respect as a positive feeling has moral commands which guide us to do virtuous things and as a negative feeling which produces pain and humiliation by doing wrong deeds (Drummond, 2006).

Adolescence is a period manifested by changes in moral thinking and behavior which gets swayed by emotions (Reed\& Ham, 1993). There is a growing pressure among adolescents and in order to deal with these challenges an enormous kind of emotions occur. Learning to cope with all those emotions entails that adolescents learn to differentiate how and when emotions are efficient from ways in which they can turn out to be negative for development, and have dysfunctional consequences (Larson, Clore and Wood, 1999). Consequently, the present study aims to study the emotions that are associated with respect among adolescents.

\section{Materials and Methods}

\section{Locale}

The participants of the current study were collected from Sikandra Road, New Delhi, India.

\section{Sample size}

The sample for the study consisted of 50 school going adolescents in the age group of 14-15 years. An equal number of boys $\left(\mathrm{n}_{1}=\right.$ 25) and girls $\left(\mathrm{n}_{2}=25\right)$ were selected for the study.

\section{Sample selection}

Using a purposive sampling technique, the investigator selected a sample of 50 adolescents who fulfilled the criterion of the research.

\section{Procedure for data collection}

For the present study, every willing participant was given written consent form to be duly signed by their parents for allowing their child to participate in the study. After receiving the consent, the participants were informed about the research area and information to be obtained from them. Right to anonymity and right to privacy were maintained in the research and names have been changed to prevent their identity.

For the data analysis, content analysis was done to identify the themes and patterns in the results obtained.

\section{Research instruments}

Keeping in mind the objective of the present study, the tools were framed in English and Hindi for easy and clear interactions in meetings with participants. Multiple 
exploratory methods were employed with participants to obtain the required information. Vignettes and semi-structured interview schedule were used to collect data from participants. The vignettes created an atmosphere for the participants to think and perceive them in that situation and reflect on their reactions to that situation taking into account the character, context and mood. The qualitative interview allowed the participants to illustrate in detail about the information required.

Incidental observation was another method that was used to obtain information about participants. It is a method that requires observing participants in their natural surroundings with minimal involvement from the researcher (Kumar, 2011). This method allows the researcher to study behavior or personality traits of an individual. Incidental observational notes were jotted down alongside.

\section{Results and Discussion}

The present study glanced at emotions that are associated with respect among adolescents. A qualitative analysis of the information generated and collected through a range of data gathering techniques facilitated the identification of certain themes. The participants were in the age group of 14-15 years studying in government schools. Out of the 50 participants, 60 per cent were 15 years old and 40 per cent were 14 years old. For the study, equal number of boys and girls i.e. 25 boys and 25 girls were selected.

\section{Feelings}

The study indicates that 36 per cent of respondents felt respected when they do not commit wrong, do not hit their friends, and do not think bad about someone and parents feel proud of them. The 28 per cent of respondents felt happy content, and joyful, followed by 14 per cent trustworthy, 12 per cent peaceful and 10 per cent proud.

In addition to it, participants also believed that if they did not respect other people then, blame would accrue to their parents who would then feel hurt (32\%) and insulted (24\%). This was also discussed by Kagitcibasi (2005) that "relatedness" is a visible feature of a collectivist culture.

In situations of disrespecting people, emotions felt by respondents were "anger" (14\%) and "sadness" (10\%). Respondents also noted that if someone disrespected them, they continued to remain respectful to those individuals who showed disrespect, the latter would perhaps experience feelings of guilt (10\%) and remorse $(6 \%)$. The enunciation that one should continue to remain respectful irrespective of the other person's behavior indicates their growing sense of moral conduct (Table 1).

Element of shame (4\%) was evident in the vignette where one boy who pushed the old lady felt ashamed after listening to so many people's criticism about his wrong behavior. This is also discussed in development of Ethics of divinity by Lene Arnett Jensen (2011), where an individual felt disgust at his own greedy attachments and felt ashamed for the action.

\section{Fear of authority}

For participants, fear was the driving force of respectful conduct. The participants were of the opinion that if they expressed disrespect, their parents would receive complaints resulting in censure $(42 \%)$, be denied the privilege and pleasure of receiving gifts $(22 \%)$ and they feared what people would think about them (20\%). This was also discussed in unilateral respect by Piaget (1965) that fear of 
the authority figure could be an aspect in respecting someone (Table 2 ).

In an interesting observation, Karan's mother called him; he asked for one minute but when his mother called again, he ran immediately following his mother's command thus, displaying obedience towards parents (16\%).

This is explained as unilateral respect by Piaget (1965) wherein the child is obliged to conform to the adult's command because there is an unequal status between two individuals.

This was also brought up in a study by Tonheim (2008) that when adolescents display respect out of fear of punishment it means that they are not acting out of unrestrained choice and passion.

Fear of being disrespectful to teachers at school for the participants would result in being given low marks (52\%), being suspended from school (30\%), and not getting praise from the teacher (18\%).

This was explained by Kohlberg (1975) in the stage of moral reasoning "punishment and obedience orientation" that explains the actions of children in accordance with the physical consequences such as punishment. Therefore, fear as one of the core emotions guides our understanding of respect.

\section{Empathy}

The respondents empathized with the person realizing the feelings of others. The data clearly indicates that participants realized the feelings of other person when they respect and disrespect them.

In the study, 38 per cent of respondents revealed that they can empathize with the positive emotions experienced by others like content, cheerful, and optimistic and 28 per cent indicated that they can empathize with negative emotions experienced by others like sadness, anger, and contempt. In response to vignette, the respondents pointed out that they would take the blame of their younger siblings in order to protect them from scolding of parents. They could not see their siblings getting scolded by parents (16\%) (Table 3).

If siblings would get scolding then they would also feel the pain (12\%). This view was further underlined in response of few participants where they responded in a positive way to help old people in crisis situations $(6 \%)$. They felt that they were able to understand the perspective of other people. The period of middle adolescence as described by Harter (1999) is more likely to be marked with empathy and understanding of others.

To sum, respect is inclusive of fear of authority as well as positive feeling of affection and consequences of transgression

\section{Emotional reciprocity}

The study revealed that 44 per cent of the participants stated that if they are respecting someone then they also expect the other person to respect them. The study indicates that in most cases where participants were questioned related to 'help' in interview; 22 per cent of the participants felt that the other person whom they helped should help them when they need it.

One of the participants during interview said, "If we help someone, it is there that in future if we need help then that person will probably help us. When discussed about the statement "To get respect, you have to give respect", the meaning participants drove from it were 'respect first to receive first', 'give respect take respect' which meant that if you want someone to respect you then first you have to respect that person (Table 4). 
Table.1 Feelings as a factor of respect among adolescents

\begin{tabular}{|c|c|c|c|}
\hline \multicolumn{2}{|r|}{ Feelings } & Frequency & Percentage \\
\hline \multirow[t]{6}{*}{$\begin{array}{l}\text { Feelings allied with } \\
\text { respect }\end{array}$} & $\begin{array}{l}\text { Felt respected by not committing wrong, not } \\
\text { hitting anyone and not thinking bad about } \\
\text { someone }\end{array}$ & 18 & $36 \%$ \\
\hline & Happy, content and joyful & 14 & $28 \%$ \\
\hline & Trustworthy & 7 & $14 \%$ \\
\hline & Peaceful & 6 & $12 \%$ \\
\hline & Proud & 5 & $10 \%$ \\
\hline & Total: & 50 & $100 \%$ \\
\hline \multirow{8}{*}{$\begin{array}{l}\text { Emotions allied } \\
\text { with disrespect }\end{array}$} & Hurt & 16 & $32 \%$ \\
\hline & Insulted & 12 & $24 \%$ \\
\hline & Anger & 7 & $14 \%$ \\
\hline & Sad & 5 & $10 \%$ \\
\hline & Guilt & 5 & $10 \%$ \\
\hline & Remorse & 3 & $6 \%$ \\
\hline & Shame & 2 & $4 \%$ \\
\hline & Total: & 50 & $100 \%$ \\
\hline
\end{tabular}

Table.2 Fear of authority as a factor of respect among adolescents

\begin{tabular}{|c|c|c|c|}
\hline \multicolumn{2}{|r|}{ Fear of Authority } & Frequency & Percentage \\
\hline \multirow[t]{5}{*}{ At home } & Criticism by parents & 21 & $42 \%$ \\
\hline & $\begin{array}{l}\text { Denial of privilege and pleasure of receiving } \\
\text { gifts }\end{array}$ & 11 & $22 \%$ \\
\hline & Others opinion about them if they disrespect & 10 & $20 \%$ \\
\hline & Obedience towards parents & 8 & $16 \%$ \\
\hline & Total: & 50 & $100 \%$ \\
\hline \multirow[t]{4}{*}{ In school } & Low marks or grade & 26 & $52 \%$ \\
\hline & Suspension & 15 & $30 \%$ \\
\hline & Not praised by teacher & 9 & $18 \%$ \\
\hline & Total: & 50 & $100 \%$ \\
\hline
\end{tabular}

Table.3 Empathy as a factor of respect among adolescents

\begin{tabular}{|c|c|c|c|}
\hline & Empathy & Frequency & Percentage \\
\hline Realization of other & Content, cheerful, and optimistic & 19 & $38 \%$ \\
\hline people's feelings & Sadness, anger, and contempt & 14 & $28 \%$ \\
\hline $\begin{array}{c}\text { Take the blame of } \\
\text { others to protect them }\end{array}$ & Cannot see others getting scolded & 8 & $16 \%$ \\
\cline { 2 - 4 } & Sense the pain felt by others & 6 & $12 \%$ \\
\hline $\begin{array}{c}\text { Understanding of } \\
\text { other's perspective }\end{array}$ & Helping people in crisis situations & 3 & $6 \%$ \\
\hline
\end{tabular}

component in life. 
Table.4 Emotional reciprocity as a factor of respect among adolescents

\begin{tabular}{|c|c|c|}
\hline Emotional reciprocity in respect & Frequency & Percentage \\
\hline $\begin{array}{c}\text { Expecting respectful behavior in return of respecting } \\
\text { others }\end{array}$ & 22 & $44 \%$ \\
\hline $\begin{array}{c}\text { Expecting helpful behavior from helped person in } \\
\text { neededpoint in time }\end{array}$ & 11 & $22 \%$ \\
\hline $\begin{array}{c}\text { Expecting good behavior in return of talking courteously } \\
\text { with others }\end{array}$ & 6 & $12 \%$ \\
\hline Helping others first to get help in return & 5 & $10 \%$ \\
\hline $\begin{array}{c}\text { Expecting bad behavior in return of talking insolently } \\
\text { with others }\end{array}$ & 4 & $8 \%$ \\
\hline Valuing time to achieve something in life & 2 & $4 \%$ \\
\hline
\end{tabular}

12 per cent of respondents believed that if they would talk courteously with other, then it would result in receiving good behavior from other person side, followed by 10 per cent of respondents believing that if they want help from someone, they should first help them and 8 per cent believing that if they would talk insolently with others ('तू' (tu), 'अबे' (abey), or 'ओये'(oye), other would do the same thing. It is parallel to the "instrumental-relativist orientation" stage of Kohlberg Moral Development Theory, which explained that individual does things according to their selfdriven interest where there would be reciprocity and equal sharing of things.

In fact for 4 per cent of the respondents, reciprocity was also seen in case of time. If the respondents do not value time, the time will not value them. Therefore, adolescents also felt that it is important to respect time as it is once gone, it will not come back and it is a very valuable

"Respect is a feeling which comes from heart nobody teaches us and we feel it from our heart"

The preceding statement discloses that respect simply means the feelings towards a person that comes from heart". There are different emotions that are felt when respect is received as well as when it is shown to other people. There are emotions that are linked with respect which includes happy, content, joyful, trustworthy, peaceful, and proud. There are also emotions that are felt when someone disrespects the person or it is felt within by someone when they disrespect other people. These emotions include feeling hurt and insulted, anger, sadness, guilt, remorse, and shame.

It was also seen that adolescents respect others as a result of fear of authority. They fear that if they do not respect other people then, their parents will be blamed. The adolescents would be deprived of various privileges and other people would form negative opinion about them. In school, adolescents' fear that teachers would not give them good marks, fear of suspension and not praised by teachers. It was revealed that love and fear were the core emotions that drive the display of respect.

The study highlighted empathy as a factor of respect among adolescents which includes realizing other person's feelings, protecting others as well as understanding the perspective of other person. Emotional reciprocity as a factor of respect was also seen where "Give 
Respect, Receive Respect" was the major point which focuses on doing good to others to get good things in return.

\section{References}

Drummond, J.J., 2006. Respect as a Moral Emotion: A Phenomenological Approach. Husserl Stud. 22(1): 1-27.

Harter, S., 1999. The Construction of the Self:

A Developmental Perspective. THE GUILFORD PRESS, New York.

Hill, T.E., 2000. "Must respect be earned?" In Respect, pluralism, and justice: Kantian perspectives, Thomas E. Hill (Eds). Oxford University Press, Oxford.

Jensen, L., 2011. The cultural development of three fundamental moral ethics: Autonomy, Community, and Divinity. Zygon. 46(1): 150-167.

Kagitcibasi, C., 2005. Autonomy and relatedness in cultural context: Implications for Self and Family. Journal of Cross-Cultural Psychology. 36(4): 403-422.

Kohlberg, L., 1975. The CognitiveDevelopmental Approach to Moral Education. The Phi Delta Kappan. 56(10): 670-677.

Kumar, R., 2011. Research Methodology: a step-by-step guide for beginners. SAGE Publications India Pvt Ltd, New Delhi.

Larson, R.W., Clore, G., and Wood, G. 1999. The emotions of romantic relationship: Do they wreak havoc on adolescents? In W. Furman, B.B. Brown, \& C. Feiring (Eds.), Romantic relationships in adolescence. Cambridge University Press, New York.

Lawrence-Lightfoot, S., 2000. Respect: An Exploration. Perseus, Cambridge.

Piaget, J., 1965. The Moral Judgement of the Child. THE FREE PRESS, New York.

Reed, L., and Ham, M. 1993. "Stress and Storm" in early adolescence. The relationship of negative events with dysphonic affect. Developmental psychology. 29(1): 130-140.

Shwalb, D., and Shwalb, B. 2006. Research and Theory on Respect and Disrespect: Catching Up with the Public and Practitioners. New Directions for Child and Adolescents Development. 114: 18.

Tonheim, M., 2008. Is respect an obstacle to or a facilitator of child participation? A study of children's participation in the cultural context of Madagascar. Childhoods Today. 2 (2).

\section{How to cite this article:}

Priyanka Panwar. 2019. Emotions as an Aspect of Respect among Adolescents. Int.J.Curr.Microbiol.App.Sci. 8(10): 755-761. doi: https://doi.org/10.20546/ijcmas.2019.810.087 